\title{
Antidumping Charges Against China: A Comprehensive Analysis Of Proponents, Opponents, And Its Impact On U.S. Companies
}

Ki Hee Kim, (E-mail: kimk@wpunj.edu), William Paterson University Cho Kin Leung, (E-mail: leung@wpunj.edu), William Paterson University Vincent J Vicari, William Paterson University

\begin{abstract}
Few nations have changed as fast-or as Dramatically — as China has since the 1970s. The world's most populous nation has radically liberalized its economy and gone from producing lowquality and simple export to sophisticated high-technology goods, while nurturing a vibrant private sector and attracting nearly $\$ 500$ billion in foreign direct investment (FDI). China's total exports grew eightfold - to over $\$ 380$ billion-between 1990 and 2003. China's share of global exports will reach 6 percent in 2003, compared to 3.9 percent in 2000. The U.S. has lost about 2.6 million manufacturing jobs since 2001. While private economists say that most of he job losses reflected improved productivity at U.S. factories, many in Congress and within industry say China blame China. China's soaring economy has turned it into manufacturing juggernaut that maintains the largest trade surplus of many nations, including the U.S. U.S. law provides for the protection of American manufacturers form unfair foreign trade practices. If U.S. companies believe that foreign competitors are dumping merchandise in the U.S. or are being subsidized by foreign governments, they may file for relief with the U.S. Department of Commerce's International Trade Administration and the U.S. Trade Commission. Antidumping levies duties on goods dumped on the U.S. market. One of the most contested issues is whether U.S. trade laws, in particular the antidumping laws, should be open to negotiation. It should for the benefits of U.S. customers and U.S. businesses. This research will focus on dumping charges against China and evaluate pros and cons of U.S. antidumping laws against foreign companies and its impact on U.S. consumers and businesses.
\end{abstract}

\section{Introduction}

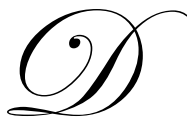

umping occurs when firms export merchandise at prices below the prices prevailing in their home market, which is sometimes, called "price-to-price dumping. "When they export for a sustained period at prices which are below their average cost of production, and producers in the importing country are materially injured as a result. Dumping is widely recognized internationally as a potentially harmful and unfair trade practice. Virtually all-major trading nations have antidumping laws, including the U.S., the European Union and Japan. During the last two decades, there have been significant developments in the use of antidumping actions, the most popular protectionist policy in use today. First, there has been an explosion in the total number of anti-dumping investigation filed. While the average annual number of antidumping initiations was 144 during 19801985, it reached 318 in 2000-2001. Secondly, while it was sued almost exclusively by the U.S. and EU, Canada and Australia until 1985 and it started to spread to other countries in 1990s. The U.S. uses antidumping legislation to address unfair trade practices by importing companies. Advocates of antidumping laws claim that they are essential in the fight against predatory pricing by foreign companies. Those opposing antidumping legislation suggest that it is just another form of protectionism that nurtures inefficient industries and increases cost to U.S. consumers. Critics 
also say that antidumping laws create impediments to free trade, which results in misallocation of global resources and the disregard of comparative advantages. This paper examines antidumping charges against China and also evaluates the pros and cons to improve trade, economic, and the political environment between U.S., China, and other trading partners.

\section{Antidumping Filing Procedures}

Requirements for filing an antidumping or countervailing duty investigations are carried out by the Department of Commerce's International Trade Administration (ITA) and by the U.S. International Trade Commission (ITC). The ITA determines the existence of sales at less than fair value or subsidy programs, and the ITC determines whether a U.S. industry is being or may be materially injured. Although the ITA has the authority to initiate its own investigations, an interested party usually starts an investigation by sending petitions simultaneously to the ITA and the ITC. In filing petitions, interested parties must include the following data: information about the petitioner, descriptions of goods and exporters, evidence of dumping or subsidization, and evidence of material injury. The U.S. antidumping system provides tremendous protections for the benefit of foreign exporters subject to antidumping investigations. They have full notice of the investigation, opportunities to review evidence and to be represented by counsel, and full rights to appeal administrative decisions for court review. Nor does the mere threat of an U.S. antidumping or countervailing duty actin impede competition.

\section{Purposes of Antidumping and Countervailing Duty Legislation}

Through its antidumping legislation, which levies duties on goods "dumped" on the U.S. market, the U.S. discourages the sale of merchandise in the U.S. at less than fair value if such sales cause or threaten material injury to a U.S. industry. By imposing similar duties, countervailing duty legislation checks the unfair competitive advantage foreign manufacturers and exporters receive from subsidies. In some instances, countervailing duties can be imposed without application of a material injury test.

\section{Dumping vs. Antidumping}

Dumping means selling imports in U.S. at prices lower than their normal value. The difference between normal value and exports price is termed the "dumping margin." Antidumping refers to a legal system under which the government of a country investigates the dumping of imports and take antidumping measures in accordance with the law. It is a measure internationally adopted to stop unfair competition, regulate international market order and protect the security of the national industries.

\section{Non-Market Economy Status of China}

In April 1998, the European Council with Council Regulation (EC) no. 905/98 gave individual Chinese and Russian companies the opportunity to claim that they operate in market economy conditions on a case-by-case basis. This regulation does not grant China the status of full market economy. However, provided that Chinese companies satisfy the requirements and dumping calculations are based on their own domestic price and costs and not those of a third country. When non-market economies are involved, Chinese antidumping regulations follow different procedures then one follows by the U.S. When dealing with a non-market economy the price of the subject product in a comparable market economy must be used. This has affected trading with China immensely since the U.S. considers China a non-market economy. Chinese antidumping regulations do not have this provision. Chinese authorities use the company's price whether in a market economy or not.

\section{Determination Fair Value}

To determine whether a product is being sold in the U.S. market at less than fair value, comparisons are made between U.S. prices of imported merchandise and, usually, home market prices (i.e., foreign manufacturer's domestic prices) of the goods in question. A home-market price can be expressed as an individual price or as a weighed average of the prices in the exporter's domestic market for a specific time period. 


\section{Establishing Material Injury}

Whether material injury results from subsidized or dumped merchandise depends upon an analysis of the effects that U.S. imports have on U.S. producers of like products. Injuries may take the form of depressed prices; lost sales; a general decline in sales, market share, profit, and the volume of dumped imports.

\section{Types of Dumping}

a. Price-to-price dumping: Price-to-price dumping can occur because the dumping industry enjoys some degree or market power in its domestic market which enables it to maintain a higher price in the home market than in export markets. This may arise out of protection of the home market from import competition (through restrictions on market entry, natural, or manmade factors); the relative absence of internal competition because of the existence of a monopolistic, oligopolistic or categorized market structure; or some combination of these factors. Absent such elements, the domestic price and the world price will equalize.

b. Below cost dumping: Below-cost dumping can occur because the industry which is dumping possesses a structural characteristic which enables it to export its products below the cost of production for a sustained period without going out of business. Such characteristics vary widely, but may include the existence of some form of government support, the ability to cross-subsidize losses in one product area with profits earned in other areas, or simply enormous which make it possible at a loss for a long period time.

c. Predatory Dumping: A foreign manufacturer may take this actin because it wishes to sell excess production without disrupting prices in its domestic market, or it may have lowered the export price to force all domestic producers in the importing nation out of business. The exporters expect to raise prices in the market one that objective is accomplished.

d. Social Dumping: Unfair competition by firms in developing nations that have lower labor cost and poor working conditions.

e. Environmental Dumping; Unfair competition caused by a country's lax environmental standards.

f. Financial Service Dumping: Unfair competition caused by a nation allows requirements for bank capital/asset rations.

g. Cultural Dumping: Unfair competition caused by cultural barriers aiding local firms.

Most governments retaliate when dumping injuries local industry. The EU, for example, levied antidumping duties of 39.2 percent on handbags from China in spite of warning from European retailers and importers that such a move would cost more jobs than it would create. In fact, antidumping suits have become the favorite means of manufacturers in the EU, the U.S. and increasingly, other nations to protect themselves from less expensive imports.

\section{Antidumping Charges Against China}

In recent years, the number of dumping cases against China has skyrocketed. From August 1979 to March 2001, a total of 422 antidumping cases had been filed against China involving more than US $\$ 10$ billion worth of Chinese exports. The European Union (EU) leads the attack, followed closely by the US. Since 1991 we have been involved and have been able to won numerous Chinese antidumping cases, including initial investigations and review investigations, at both the Commerce Department for low dumping margins and at the US International Trade Commission (ITC) for no injury. Many of these cases involved Chinese chemical or metal products, such as refined antimony trioxide, sulfur dyes, silicon carbide, saccharin, sulfanilic acid, and polyvinyl alcohol (PVA), including farm products such as garlic. Although the U.S. importers participated in the garlic case, we could not persuade the Chinese exporters. US importers told blank by he Chinese exporters, The U.S. market is not important for us. Since the Chinese exporters refused to participate at the DOC, the DOC had no choice and gave them the entire 376 percent antidumping margin alleged by the U.S. industry in the petition. The effect of the garlic determination was a complete disaster as all Chinese garlic has been shut out of the U.S. market since 1994. 
After garlic case, the same law firm brought the dumping cases against Chinese honey, bicycle, mushrooms, silicomanganese, crawfish, iron castings, carbon steel plate, and brake rotors. On August 20, 2002, U.S. Department of Commerce made a final determination the pure magnesium in granular form produced in Canada or any other third country from pure magnesium ingots produced in China is within the scope of November 19, 2001, antidumping order on pure granular magnesium from China.

\section{How to Solve Antidumping Charges against Chinese Companies}

There are a number of strategies that Chinese exporters and producers can use in the initial investigation to increase their chances of winning the case. Chinese exporters should follow to win an antidumping case is to work with the importers. In many cases, Chinese exporters have decided to go it alone, and the result has been disaster. Although the Chinese exporters may have control over their own data, they do not understand the situation in the U.S. market. At the ITC, the importers are the only parties that can effectively argue against the U.S. industry. Moreover, importers can persuade the end user, which is an U.S. producer, to testify on behalf of the Chinese at ITC and the DOC. Another very important reason for working with the importers is-politics. U.S. producers that use Chinese raw materials can bring substantial political pressure to bear on the DOC and the ITC because U.S. jobs may be dependent on the imported raw materials from China. Because importers are such an important factor in winning an antidumping case, Chinese exporters should not try to cut them out of the case and go it alone.

\section{U.S. Antidumping Law Hurts Americans: Pros and Cons}

Despite evidence of significant welfare costs and misguided economics of antidumping, the law continues to enjoy widespread support among policy members. Even members of Congress who represent export intensive states have little or no important competing constituents. Why is that? It has something to do with the fact that efforts to dissuade this type of protectionism have been less rigorous than efforts to encourage it. The benefits of protection accrue to a small group of concentrated producers while the costs are spread among a larger cross section of import users and consumers, so inherently there is a greater motivation to seek protection than to challenge it. It is, therefore, incumbent upon adversely affected constituencies to recognize that their consolidated stakes are higher than those of the protection-seekers. Policy makers in the antidumping arena have given the interests of importers, import-using industries, and consumers short shrift. Defenders of the antidumping law like to argue that antidumping is a trade lubricant. By maintaining an antidumping law, constituencies that face the greatest challenges from open trade are more apt to buy into trade liberalization, generally. Antidumping laws have long been abused by protectionist U.S. industries seeking a reprieve from foreign competition. However, in recent years, the tales have begun to turn and U.S. exporters are increasingly under target from foreign governments flexing their own antidumping muscle. Despite this trends, an alarming number of U.S. policy-makers have declared antidumping sacred cow, off limits to revision and discussion in any future trade agreements. This position risks stalling future trade talks because other countries may balk at opening their markets if we refuse to reform our own trade barriers. Furthermore, U.S. antidumping supporters ignore the new reality: antidumping laws are proliferating rapidly worldwide, closing or limiting markets to U.S. exporters at a growing clip, threatening to reverse gains achieved through years of market access liberalization. While American politicians lecture the world on fair trade, our dumping laws are an inquisitorial nightmare for foreign companies, making mockery of due process and justice at every turn. The crime of dumping most often occurs as the result of the American government's bureaucratic manipulation of numbers rather than actual foreign business practices.

\section{Conclusion}

The likelihood of continued antidumping proliferation a significant threat to U.S. export growth. As the world's largest exporter, the U.S. should expect to be targeted even more as new countries learn how to wield the antidumping hatchet. Traditional trade barriers are still high in developing countries, which will find great comfort in the availability of a WTO-sanctioned tool to replace those barriers. It is difficult to imagine how China, heretofore relatively restrained in its antidumping actions, will be able to resist pleas from its import-competing industries for antidumping assistance, particularly since it has endured the most antidumping abuse. The antidumping law, and the related countervailing duty law, provides an important internationally recognized remedy 
against foreign unfair trade practices. These laws are essential to ensuring that international economic competition is based on free market principles, and that U.S. government intervention and tolerance of private anti-competitive practices are not allowed to distort market forces. Rather than being attacked, these laws should strengthened.

\section{References}

1. $\quad$ Foreign Affairs; Nov. /Dec., 2003, Vol.82. Issue 6, :epnet.com/citalion.aspptb.

2. $\quad$ Alan Wm. Wolff, Tole of the Antidumping Laws, May 3, 1995.

3. Chad P. Bown, B. Hockman, Caglar Ozden, Obstacles Facing Developing Cases; The path From Initial Filing to WTO Dispute Settlement, May 14, 2003.

4. Nadeem M. Firoz, and Ramon E. Garcia, Antidumping War Against China and the Effects of WTO Membership

5. http://www. Lectlae.com/files/for ol.htm, U.S. Antidumping/Countervailing Duty Legislation. Learned:http://www.glassbytes.com/030701dump.htm.

6. Brink Lindsey and James Sumner, The Antidumping Epidemic, Cato Institute Policy Forom, Ocr. 30, 2001.

7. Dan Ikenson, “Antidumping Law Hurts Americans,” December 27, 2003.

8. David R Grace, Alexia, and Yao Feng, China's Antidumping Regime, Feb. 17, 2003.

9. James Bovard "U.S. Trade Laws Harm U.S. Industries," The Review of Business and Government.

10. U.S. Dept. of Commerce-International Trade Administration, "U.S. Antidumping and Countervailing Duty Legislation," Rev. 1/91.

11. EU Leads Surge in Antidumping Claims," Financial Times, April 17, 2000 and "Dumping Duties on China," Financial Times, February 6, 1997.

12. "The New Rules of Trade," National Review, April 18, 1994.

Notes 
Notes 